\section{THE REPORT OF THE VACCINATION CoMmission.}

DR. JoHN FRYRR (Dewsbury) writes: I have just, heen reading the "summary" of the fnal rep.rt of the Royal Commistion appointed to inquire into the subject of Vaccination, given in the reprint of the BAITiSB MEDICAL JOURNAL (Vaccination racts and Problems). I have a precis or digest of evidence taken before a Committee of the House of Commons, on the Vaccination Act, 1867. Can you tell me of a similar aprecis or digest of the evidence given before the Royal Commission appointed in 1889 , whose report was issued in August. 1896 ? The pritnesses' evidence given before the Commission.

*** There is unfortunately no such summary or digest. The evidence is contained verbatim in a series of large Blue Books, which with one exception have a very good index. The exception-the Sixth Reportis the largest and. in some respects. the most important of all, but the want of an index makes it almost useless for purposes of reference, 1 excepting to the most laborious student. As indicated at the end of the article referred to by our correspondent, the statement of dissent from the Commissioners' final report has been fully reviewed in the Transactions of the Epidemiological Society for $18,6-7$.

\section{ANSWERS,}

TirenapeUTics. - We regret that we have not been able to obtain information as to the cowposition of the secret remedy in question.

J. H. - Information on the subject of phenazone and cosl-tar compounds is contained in Dr. H. C. Wood's Thercyeut,cs :
Practice. London: Smith, Elder, and Co. 1902. 188.

G. M. S. - The following is the information required by our correspondent:-A Studu of 978 Cases of Small-Pox with Reference to the the Glasgow Medical Journal, 1872-3. Giasgow: Dunn and Wright, 1873: $8 \mathrm{vo}, \mathrm{pp} .20$.

REgULATIONS FOR THE F.R.C.S.ENG.

MR. N. D. DARÛ.-The Royal College of Surgeons of England accepts as an equivalent for the frsi and second examinations of the English Conjoint Board a certain number of university examinations and therefore admits those who have passed them to its first Fellowship examination, but those passed by an L.M. and $S$. of an Indian university are not among them. The college also admi's to its second Fellowship examination those who, though not Members of the College, nevertheless hold the registrable medical and surgical degrees of certaiu universities; among these are the Universities of Calcutta, Bombay, Madras, and the Punjab, but no anomaly such as that to which our corresponc.M. and $\mathbf{s}$. which some or all of these universities grant. as a diploma and not as a degree.

House Sanitation.

SECRETARY. - There are a large number of books dealing with house sanitation in a greater or less degree, but we know of no one volume covering the whole subject. G. A. T. Middletion has writiten several hooks on the subject (Batsford). S. S. Hellyer's Plumber and innitary Honses (Batsiord, 128. 6d.). or the same author's Theory and Practice of Coleman's Sanitary House Drainage (9pon. 6s.), or Latham's Sanitalion of Domestic Buildengs (Sanitary Pub'ishing Company, 2s. 6d.). might nieet Domestic Buildengs (Sanitary Pub'ishing Company, 2s. 6d.) might mieet
our correspondent's requirements. There is a.lso much useful watter on house sanitation in the ordinary public-health textbooks (Whitelegge, Notter and Firth, Parkes and Kenwood, etc.).

\section{EDTYARs, NOTES, Ete.}

ERRATUM.-In the heading of a paper on gastro-jejunostomy and jejunojejunostomy in cases of chronic ulcer, published on October $29^{\text {th }}$, the fact was not stated that the author, Dr. T. Gelston Atkins, is Surgeon to Cork South Infrmary and County Hospital.

\section{A Correction}

THE $\oint_{2,0 c 0}$ contributed to the schools of the Lancashire and Cheshire Bociety for the Permanent Care of the Feeble-minded, referred to by our special correspondent in Manchester Jast week, p. 1269, was received Education Committee.

BORN WITH THE MORPBINE HABTT.

HAMLET, in condemning the hard-drinking habits of the Danes, by whioh Shakespeare doubtlese meant the English, admitted that he was to the manuer born. We learn from Lüızöft (" $E$ t Tilfaelde af medfödt Morfinisme," Hospitalstidende, No. xlix, rgo3) of another, but not Royal, Dane developed child, with no sign of malformation or prenatai disease, showed extreme restiessness from the first moment of extrauterine life. It could not be got to sleep, it cried incessantly, and its fentures bore an expression of pain. For over two days it could not be induced to take any kind of nourishment, and its life was despaired of. Half a minim of tinctura thebaica was administered three times daily, that compound, whicn holds a place on the Danish Pharmacopoeia, being made up, as we learn from Squire's Companion. of oplum. 6 parts ; henzoic acid, 6 ; camphor 4 ; oil of avise, 3 ; and diluted alcohol, 1,200 For the first time in its Jife - that is, on the third day-it became tranquil, all the restlessness subsiling, and ul imatelo it throve. The opiate was lessened gradually, which, as the child's countryman aiready mentioned would say, lent a kind of easiuess to the next abstinence. It is now getting on without the narcotic, but its after-history, wh
delivered from the womb of time, will be, in any event, of interest

LETTERS, COMMUNICATIONS, ETc., have been received from :

A Dr. T. G. Atkins, Cork; Mr. F. Addiscott, Lon on; A. B. C.; Dr. S. J. Aarons, London; A. D.; Ajax; Ariel Cycle Company, Secretary of, Birmingham; Alpha ; Mr. T. A. H. Anderson, Glasgow; Auti-Sixpence; Messrs. Allen and Hanb irys, Lor don. T Dr. C. W. Branch, St. Vincent; Mr. W. H. Brown, Leeds; Dr. W. Bulloch. L indon Beta; Rev. J. L. Brooks, Lingtield ; Dr, O. Buttar, London; Dr. W. Bruce, Dingwall Dr. C. L. Birmingham, Dublin; Mr. W. M. Bristow, Liscard; Mr. A. J. Briant, Helsby. pool; Dr. A. V Clarke, Leiceat ir; Mrs. Cortwal', I on ion; W. J. Oa'e, M.B, ury St. Edmunds; Dr. G. A. Casalis, London; Dr. J. R. Colluns, Cheltenham; Dr. G.
Ci ichton; London; H. S. Clogg, M.B., London; Dr. E. Cullinan, London. I Dr. D. Drew Ci ichton, London ; H. S. Clogg, M.B., London; Dr. K. Cullinan, London. D Dr. D. Drew,
London; Miss M. Dendy, Manchester; R. Dunsmuir, M.B., Renfr w ; D. R. D., M.D. F.R.O.S. E Dr. G. Elliott, Toronto; Messrs. Ereck.on and Co., London. F. Mr. J. Fryer, Dewsbury; Far East ; Mr. A. T. Falwasser, Maidstone; Fair Pl *y; F. A. Foy M.B., Rangoon. G Grafton Press, Mannger of, New York; G. B. Gill, M. B., Belper Dr. W. Gosse, Sittingbourne; G. S. Graham-Smith, M. B., Cambridge; Goldthorn ; Geographical Society, Secretary of, London; Mr. K. W. Goadby. London; P. G. Griffith, M.B., ondon; Mr. W. H. J. Galbraith, London; Dr. G. T. Gifford, Black ; P. G. Griffith ; Mr. H. B. Gardner, London; Mr. W. C. W. Glenny, Omeath; Mr. G. L. Gomme, London; Sir W. R. Gowers, Lou,don; Dr. E.W. Goodall, London. F H. B.; Harrogate; Dr. P. S. Hichens, M.B., Glasgow ; Dr. C. O. Hawthorne, London; Dr. Hart, London; Dr. R. T. Hallday Harrison, Hull. J Dr. W. M. Jone,, Torquay; Dr. J. Johnston. Bolton; Mr. T. Juhneon, Clifton; Mr. H. Jones, Hereford; Mr. N. H. Joy. Bradflid. K Mr. F. W. Kendle, South Molton; Mr. W. G. King, Lon ion; C. Killick, M.B., Muidstone; Dr. J. H. Kfay, London; Mr. T. G. Kerr, London. L J. J. Langston, London; H. Lett, M. B.. London; G. R. Livingst-1:, M.B., Dumeri-s; Mr. J. I awrence, Lonilon ; Liverpon Medical Institution, Secretary of. Liverpool; Mr. F. T. B. Logan, Bristol; Mr W. Lloyd, London. M Dr. J. Mackenzie, Burnley; Mr. M. M. McHardy, London: Mr. W. H. Martiudale, London; Mr. E. Merck, Darmstadt; Dr. C. F. Marhall,
Birmingham; Mr. M. C. Moxham, Boston, Lincs.; Mr. E. R. Morgan, Moriston; Dr. E. Birmingham; Mr. M. C. Moxham, Boston, Lincs.; Mr. E. R. Morgan, Morriston; Dr. E. Magennis, Dublin; Mr. G. Mann, Oxford; Mr. W. J. Morton, London; Mr. C. Meares,
London Dr. R. Marsh, Hove; Dr. J. Me calfe, Biad ford; H. McLaren, M. B., Glasgow London Dr. R. Marsh, Hove; Dr. J. Me calfe, Biad ford; H. McLaren, M. B., Glasgow ;
Mr. R. J. Montgomery, Dublin; M. J., M.B., C.M. N Mr. E. Nicholson, I iverpool Mr. R. J. Montgomery, Dublin; M. J., M.B., C.M. N Mr. E. Nicholson, I iverpool. D I r. H. O'Neill, B lfast; Obstetrical Society, Secretary of, Lor don. P Mess's. Keqain
Paul, Trench, Trubner, and Co, Lond ('n; Pulsometer Engineering Company, Manager Pau, Trench, Trubner, and Co, Londun; Pulsometer Engineering Company, Manager Power, London. R Mr. J. Ruberts vn, Edinburgb; Mr. H. M. Raven, Broadsta rs J. D. Russe'l, M.B., London; Dr. J. W. Robertson, Peterborough ; Mr. G. E. Ru sell. Stewart, London; Sheffield Medico-Chirurgicsl Society, Secretary of, Sheffield. Mess s. Sherratt and Hughes, Maıchester; Mr. T. E. Saxby, Baltasound; Dr. S Sunderland, London; Mr. G. M. Sharpe, Leeds ; Dr. A. SqImon, Florence; Sarawera Sigma ; Ds. E. H. Snell, Coventry; Mr. A. L. M. Strong, Glasgow ; Dr. G. A. Sutter land, London. T Therapeutics; Dr. G. C. Taylor, Lond $n ;$ Mr. C. Tuch fleld, London Dr. R. Turner, Liverpool : Mr. W. Tiplady, Newcastle-on Tyne; Mr. J. Tibbeits, StokeDr. R. Turner, Liverpool : Mr. W. Tiplad y, Newcastle-on Tyne; Mr. J. Tibbelts, Stoke-
on-Trest; A. D. Thomson, M.B., Macclesfield ; Dr. F. J. Tresilian, Enfleld A. H Thoman, M.B.. Vewsley; Dr. W. H.M. Telling, Leeds. V Viator; Verbum Sap. W Dr. O. A atson, M.B., Edinburgh; Mr. J. r. Williams, Barron-in-Furness ; R. S. Williams,
M.B., Liverpool; Dr. J. S. F. Weir, London; Mr. E. H. Willock, Croydon; Dr. F M.B., Liverpool; Dr. J. S. F. Weir, London; Mr. E. H. Willock, Cro
Willcocks, London; Mr. W. B. Winckworth, Taunton. X X. X. D. D. S.

\section{BOOKS, ETC., RECEIVED.}

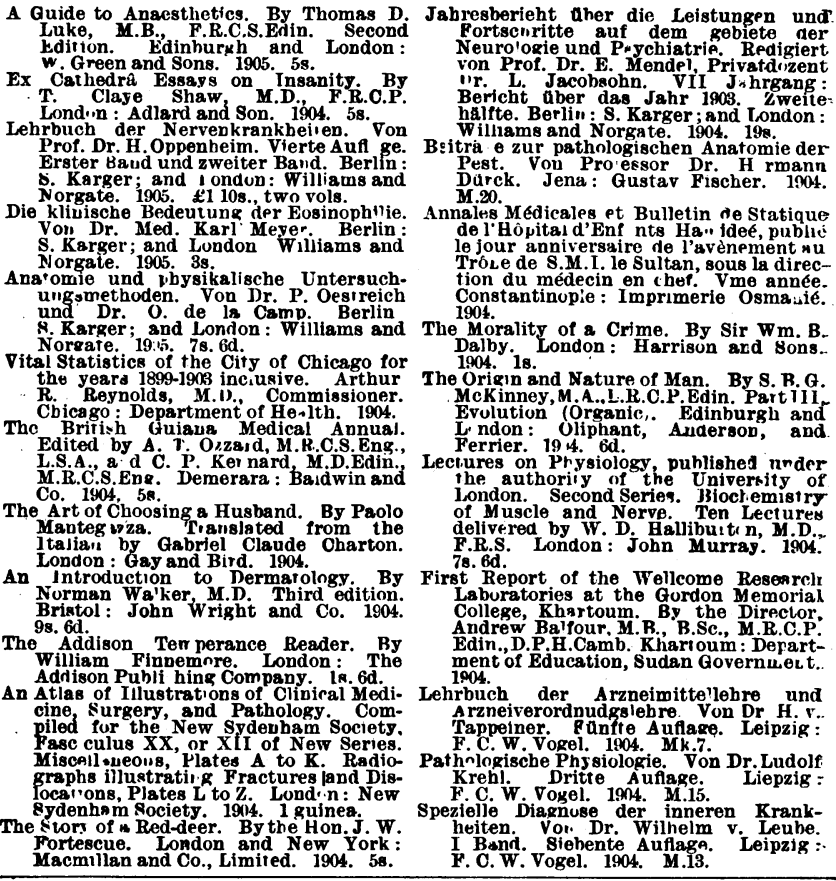

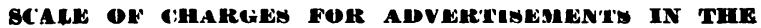
RIRTISH MEDICAI JOURNAL.

Eight lines and under

Each additional line..

$\begin{array}{llllll}\ldots & \ldots & \ldots & \text { to } & 4 & 0 \\ \ldots & \ldots . & \ldots & 0 & 0 & 6\end{array}$

A whole column

200

A page

An average line contains six words.

Advertisements should be delivered, addressed to the Manager, at the Office, not later than first post on Wednesday morning preceding publication; and if not paid for at the time, should be aceompanied by a reference.

Post-Office Orders should be made payable to the British Medical Association at the General Post-()fice, London. Small umounts may be paid in postage-stamps.

N.B.-It is against the rules of the Past Office to receive letters at Postes Restantes addressed either in initials or numbers. 